\title{
Academic casualisation in Australia: class divisions in the university
}

Tony Brown, James Goodman, Keiko Yasukawa

University of Technology, Sydney

Journal of Industrial Relations 2010, v52, n2, pp169-182

\begin{abstract}
:
Casualisation of teaching has become a major issue in Australian universities. In 1990 casuals delivered about a tenth of all university teaching. By 2008 between a third and a half of university teaching was being delivered by casuals. Quantitative studies have assessed the scale of casualisation; this qualitative study addresses the experience of casual academics. It documents a sharpening class divide amongst academics, which has become institutionally embedded. It reports on interviews with casual academics examining how the divide is experienced, and how it may be addressed. Academic casuals report underpayment and compromised quality; they experience persistent income insecurity; and they find themselves voiceless in the workplace. These experiences are interpreted as aspects of class subordination, and possibilities for addressing them are discussed.
\end{abstract}

\section{Introduction}

The academy has been increasingly recognised as a significant site of neoliberal flexibilisation and managerial rationalisation. In Australia the university sector became an important industry with the advent of mass higher education from the late 1980s. With deepened neoliberalism, the new 'enterprise’ university (Marginson and 
Considine 2000) has begun to resemble a flexibilised factory. In 1998 Ritzer’s comments about the 'McUniversity' 'roused a sleeping dragon' and stimulated a broad debate about university rationalisation and the resulting managerial iron cage (Ritzer 1998; Hayes and Wynyard 2002:1; Tuchman 2009). A key dimension of the flexible university, as in the wider economy, has been a stark divide between a relatively secure manager class and the growing army of casuals, what Berry identifies as the 'new class line' in the academy (Berry 2005). Governments have encouraged this by squeezing public finance, but ultimately, it is university management that is responsible for the casualisation of academic teaching, using it to release funds for other priorities. University managers enjoy a relatively secure income flow, but choose to impose income insecurity on an increasing proportion of the staff responsible for face-to-face teaching. Indeed, while universities are public entities, many university managers are heavily committed to neoliberal flexibilisation strategies (Gould 2003), and identify as CEO’s (Nelson and Watt 2004:8).

Where this leaves continuing academic staff is a matter of conjecture. Nelson and Watt argue that 'many tenured faculty are apparently perfectly happy to sustain their own salaries and benefits through the exploitation of other campus workers' (Nelson and Watt 2004:9). For Berry, the key 'class line is not between contingent and regular faculty... [but] between contingent faculty and those who own, control and manage institutions of higher education’ (Berry 2005:12). He argues that continuing academics are in an ambivalent position, positioned as workers in relation to central management but as supervisors in relation to casuals (Berry 2005: 12). Callinicos comes to a similar position, stressing that casualisation has proceeded hand-in-hand with the 'proletarianisation' of continuing staff as 'highly qualified wage labourers' 
(Callinicos 2006:26). The immediate impact is felt at the intellectual 'coal face'. Bryson finds that casual positions are no longer apprenticeships, but simply operate to commodify labour, with no prospect of career advancement (Bryson 2004). For Kimber, casualisation presents a 'fundamental challenge to the academic profession as it is splitting it in two - the tenured core and the tenuous periphery' (Kimber 2001:49). The division is gendered, with women concentrated in the periphery where they are denied access to an academic career (Probert 2005; Cotterill, Jackson and Letherby 2007). Casuals on the periphery are deskilled and marginalised in scholarly life, threatening the status of higher education as a public good, and thereby redefining fields of knowledge (Abbas and McLean 2001).

To investigate the new class divides, this article focuses on the class experience of casual academics in an Australian university. The casual class may exist 'in itself', as revealed in quantitative surveys of the sector (see Junor 2004), but how is class status experienced by casualised academics? The article seeks to answer this question on the basis of qualitative interviews with academic casuals, and is organized into three sections. The first outlines the industrial context, the second defines the approach and the third analyses the interviews. Three themes are highlighted: job satisfaction and work intensity; life course and insecurity; and casual identity in the workplace. Each is interpreted through the lens of class identity and the conclusions speculate about possible limits to the casualisation process.

\section{Casualisation in Australian higher education}


Once commonly understood as irregular work, casual employment has been normalised as a key feature of work in Australia's 'flexible' economy. Australia is second only to the US, in terms of OECD casualisation rates (Campbell 2004). In 2008 the Australian Bureau of Statistics found that over a quarter of the Australian workforce was employed casually, across all industries, many with multiple jobs, preferring more hours of work (ABS 2008). In 2003 the Australian Council of Trade Unions' (ACTU) 'Future of Work' study found that half of the casual workforce had been in their job for more than twelve months without access to holidays or sick pay, and that two thirds wanted continuing employment (ACTU 2003a; ACTU 2003b; Watson, et al 2003).

Within Australian universities the overall proportion of casuals in the workforce has risen from eight percent of full time equivalent staff in 1990, to fourteen percent in 1996, and seventeen percent in 2006 (AVCC 2004; DEEWR 2007). Between 1999 and 2001 the number of continuing staff in the sector fell slightly, while the number of full-time equivalent casual teaching positions rose by 240 percent. In 1990 casuals accounted for eleven percent of full time equivalent employees in academic teaching, but by 2001 they accounted for twenty-nine percent (AVCC 2003). A 2008 report on casual academics from the Australian Learning and Teaching Council suggested the figure had risen to between forty and fifty percent of full-time equivalent university teaching staff (ALTC 2008).

In 2008 a Federal Government review of the university sector headed by Professor Denise Bradley officially acknowledged the problems of casualisation. While Final Report proposed a more deregulated system it affirmed the need for an increase in 
public funding in part to reduce casualisation. Stating that 'sessional staff experience income insecurity, workloads beyond their paid hours, and feelings of isolation from the university community', the Report raised concerns about the impact on workforce renewal, as 'casualisation of the academic workforce has reduced its attractiveness as a profession’ (Bradley et al 2008: 23, 71).

The Bradley review highlighted a clash between flexibility and quality, against a background of reduced public funding and rising enrolments (Percy and Beaumont 2008). Student satisfaction was found to have fallen, suggesting 'that the greater productivity and outputs of the sector... are being achieved at the expense of time spent with individual students, good feedback on assessment and social interactions' (Bradley et al 2008: 71). Noting 'there are now relatively fewer full-time staff involved in teaching or in the delivery of courses', the Report found that casualisation and other 'productivity’ measures threatened quality (Bradley et al 2008: 71,101).

A key factor has been increasing enrolments, up by more than a third between 1996 and 2006, to 1,029,846 (AVCC 2005a; DEEWR 2008a). Universities responded to resulting pressures by seeking other sources of revenue, such as from overseas students, and by cutting unit costs. Continuing staff are relatively well organised through the National Tertiary Education Union (NTEU) and the Community and Public Sector Union (CPSU), and nationally coordinated-collective bargaining through the NTEU has maintained salary rates (AVCC 2005b). The implicit trade-off has been an intensification of work, with the student-staff ratio rising from thirteen students per staff member in 1990 to twenty in 2006 (AVCC 2008). Consequently, studies show that academic stress levels have risen, and the question of academic 
workloads has become a major industrial issue (NTEU 2004).

Increased student teaching load that is not picked-up by continuing staff has been transferred to the growing cohort of casuals. Casual academics are contracted by the hour from semester to semester as tutors, lecturers, or subject coordinators, with no guarantee of further employment. They face an enforced income break between November and March, and need to be available when teaching is distributed, usually on a take-it or leave-it basis at the beginning of the academic year. They are not paid on public holidays, nor are they entitled to paid leave, although a leave loading is included in the hourly pay rate. Casual teachers do not have continuous service so are not entitled to long-service leave, and the employers' superannuation contribution is set at the Award rate, generally half that of continuing staff. Perhaps most important, unlike continuing or fixed-term staff, casual teaching staff are not paid to develop and maintain their knowledge-base, yet are expected to deploy it in the teaching process.

The NTEU has sought to address the concerns of casual academics, although its membership remains dominated by continuing staff. Through the 1990s the NTEU successfully secured a phase-out of teaching-only continuing and fixed-term positions, creating a unified career structure for the sector. In response, universities expanded the use of teaching-only casual contracts, and created a new and more deeply entrenched two-tier system. Trade unions in other industries have sought to address this problem by campaigning for casuals to have the right to convert to continuing status after some specified period. In 2003, for instance, Unions NSW launched a secure employment test case seeking an entitlement to opt for permanent employment after six months service with the same employer. In February 2006 the 
case was successful in the NSW Industrial Relations Commission, requiring acrossthe-board amendments to State awards, although this did not have follow-on effects for university staff (NSW IRC 2006). The NTEU has used enterprise bargaining to secure conversion rights for casual administrative staff, but for the most part has failed to achieve this for academic casuals.

\section{Approach}

A key objective of our investigation was to delineate the specific experience of academic casuals. Most studies of casualisation in Australia take a quantitative approach (Wooden 1999, Buchanan 2004, Campbell 2004, Productivity Commission 2006). The 2004 'Only a Casual’ report by Pocock, Prosser and Bridge is an exception as it addresses the experience of casuals across a range of industries, using qualitative interviews. We adapted the interview instrument from the 'Only a Casual' report to reflect the findings of a separate quantitative study of academic casualisation by Junor (2004). The research thus was aimed at filling a gap in the literature, to offer qualitative insights into the experience of casual academics.

The studies by Pocock et al (2004) and Junor (2004) challenge claims that casual employment is a preference or that it provides the casual workers with flexibility. On the contrary, both studies revealed that the majority of casuals would prefer a more secure form of employment, and that the precarious nature of their employment had impacts that were broader than those related to pay, although income security was clearly a major concern. Many of the participants in their studies also raised issues about lack of control of their work and life balance, marginalisation in the workplace, 
and life and career chances. Viewed in the light of both the 'Only a Casual' and Junor studies, we opted to focus our investigations on the experience of casual academics in terms of job satisfaction, income insecurity, and identity in the workplace.

\section{Casuals at 'City University'}

The study was conducted in two highly casualised faculties in one of Australia's most casualised universities, which we are calling 'City University'. Twenty-two percent of full-time equivalent positions were casualised at this university in 1998; by 2001 the proportion had reached thirty percent (AVCC 2003). In 2001 the University conducted a survey of its 5,944 casual academic staff, and 3,596, or fifty-eight percent, responded.

The survey confirmed that a large number of casuals were engaged in delivering core teaching, were dependent upon their casual income and aspired to continuing status. Against this background, we decided to focus on casual academics who, according to the Junor typology, were 'academic apprentices' or 'qualified academic job seekers' (2004: 286), as they were most likely to reveal the lived experience of casual status. Interviewees were self-selecting; after responding to a general email sent to all casual staff in the two Faculties they arranged to meet with the interviewer, who was unconnected to the university. The anonymous interview tapes were transcribed offcampus, and then analysed by the paper's authors: in the account here, the names of the interviewees have been changed. In total, twenty-five one-hour interviews were conducted.

Of the twenty-five interviewees, eighteen were women, and seventeen were in the 
thirty-to-fifty age-bracket. Thirteen of the interviewees had children or other dependents and twelve of these were living in dual-income households. Of the remainder without dependents, there were eight interviewees in dual-income households and four in single-income households. Five interviewees had a household income below twenty thousand dollars, seven had an income between twenty and thirty thousand dollars, and five had an income between thirty and forty thousand dollars. In terms of educational qualifications, all had undergraduate degrees, thirteen had Masters degrees and five had doctoral degrees. Significantly, fifteen of the interviewees were enrolled in post-graduate degrees, including twelve in doctoral studies.

\section{Experiences of academic casuals}

The following discussion is designed to shed some light on how casual academics experience their class status, is organised into the three strands of analysis: job satisfaction, income insecurity, and workplace identity.

\section{Work intensity and job satisfaction}

The casual academics interviewed in the study, like all casual academics in Australian universities whose wages and conditions are defined in the institution's collective agreement, are employed on semester-long contracts. The meaning of these contracts is the subject of much confusion, and in some cases cynicism among casual academics. Some, like Kate, are frustrated they cannot distinguish between what is explicit in their contract and what is implicit: 
I don't understand what it is that I'm getting paid for and I've never been given clarification even though I’ve sought clarification. (Kate)

At City University it is assumed that there are two hours of 'associated duties' for every hour of casual face-to-face tutoring. These two hours encompass research and scholarship required for the session, planning and preparation, student consultation, sending and responding to emails from students, photocopying, posting materials on a web-based platform, and up to twenty minutes of marking. A recurring concern is being unable to perform the full range of 'associated duties' within the allotted time 'It's a hard balance to do what you think is right for the students and also not feel like you're... being unnecessarily exploited' (Lola).

Inadequate payment for marking and for giving student feedback is a key source of frustration. Alice spends about double the allocated time for marking and feedback:

I suppose it takes 15, 20 minutes for each one... I just can’t see the point in teaching if I don’t respond to them.... But I'm shitty about it and I'm starting to wonder whether it's worth it. (Alice)

Some interviewees also mentioned additional costs incurred from casual teaching - such as transport costs, the cost of buying books, of having a home computer, printer and email and of providing for child care. Charlotte describes this as a 'negative earning issue', of having to 'pay $\$ 80$ to come to a meeting for which I’m paid \$25’. 
Despite the poor pay and recognition, the interviewees expressed a strong commitment and dedication to their vocation as teachers, and an appreciation of the intellectual demands of the work. The relationship with students is at the core of their job satisfaction:

I genuinely love it. I enjoy the intellectual growth, which has to occur as part of it ... my students are very good ... I'm sure at the end of the class I've learnt as much as they have, so I enjoy that immensely. (Scott)

Casual academics are often told not to work beyond the hours they are paid for, even though it is generally known this is not realistic if students are to receive an adequate standard of tuition. Winnie sums up the resentment that emerges:

Winnie: I'm involved with the students, I really appreciate the students, I love teaching, I love watching their learning process. I get inspired by that. But that's the only thing that keeps me going. Interviewer: It's very reliant on that though. Winnie: Absolutely. They get the best of us for bugger all. (laughs) (Winnie)

The payment regime for casuals defines both the rate of exploitation and the limit to quality, suggesting that for casual academics teaching quality is experienced as a class issue.

\section{Life course and insecurity}

Despite working for established educational institutions, within programs of study that year-on- 
year have a predicable student intake, academic casuals are employed semester-by-semester, analogous to seasonal workers (see Husbands and Davies 2000: 365). They live with a permanent sense of income insecurity: paid work is strictly limited to semester time, often with limited hours, and with no guarantee of work from one semester to the next.

The result is that the casual academic workforce is a highly marginalized, albeit professional, segment of the workforce. Rick is especially angered by the common practice of calling in casuals at the last minute:

It's unfortunate when academics ring up three days before semester's start and say, “just confirming the work” - I think that's disgusting (Rick)

For some, the uncertainty is demeaning. Due to a delay in the processing of her contract Juliet was not paid until six weeks into the semester, and she felt it was 'just really disrespectful, and humiliating to have to then go and say I need to be paid because I need to pay my rent'. Uncertainties about re-engagement breed a sense of vulnerability. Barry illustrates how this works:

I think that I'm safe to assume now that I will be offered work next semester, unless I’ve pissed somebody off by ranting and raving too much. But it's not confirmed officially, generally, until a few weeks out. (Barry) 
Importantly, many interviewees stressed that casual academic work was not flexible: casuals cannot negotiate their workload, nor when they work. They are offered work on a take-it or leave-it basis, sometimes at the last minute. Those with another income source, such as a research degree scholarship, tended to feel more secure. Many interviewees would prefer an arrangement that allowed more flexibility for them rather than for the University. Winnie, for instance, is adamant:

Interviewer: Some people say that being casual gives you flexibility...

Winnie: Crap ... It doesn't suit me at all. I'd much rather work fulltime.

Kaz laughs at the mention of flexibility:

Interviewer: Some people say that being a casual gives you flexibility, what do you think of that statement?

Kaz: (laughs). I think - I have no money for Christmas presents for my children. (laughs). I think that's a bit bogus. ...I'd have a lot more flexibility if I knew my timetable from year to year, .... As it is, I teach casually at three or four institutions, they're all on different timetables, it’s a nightmare.

For many casuals the seasonal nature of casual academic work creates major financial problems. “The big difficulty about working casually, especially teaching, is that when the semester's not on you're not getting paid” (James).

The lack of regularity, security and predictability of income has wider effects, in terms of lifecourse. 
Interviewer: On a more personal level, you mentioned before about not knowing when your next job's going to be, how does that affect your ability to plan as far as housing, holidays, children.

Kaz: (laughs). That's a very stressful question. Interviewer: Sorry. Kaz: No, no, it’s alright, ... it’s completely impossible. I can’t plan financially speaking - it's very difficult to have your wages drop out at the middle of November and not pick up again until the beginning of March. ... the best I can succinctly say is that that's very harrowing. (Kaz)

Despite the problems of casual work, some continue to work in universities in the hope that this will eventually lead to an academic job with greater security. Those working as a casual academic while studying for a research degree with a scholarship and an internship tended to be more optimistic:

They guarantee me work, from two to six hours every semester of my $\mathrm{PhD}$ candidature to get your foot in the door. ... And I think that it will work that way for me. (Nell)

Charlotte, on the other hand, while also seeking security, saw a decreasing number of continuing positions available, especially at the lowest 'Lecturer A' level. The result is frustration and disappointment. A few who were interviewed have all but given up waiting for suitable vacancies to emerge. Marie has 'hit the dust': 
I thought that if you were a good casual and reliable and did more, did good work that would give you some added value in the workplace and would help... I think in a normal workplace it would ensure that you got some sort of permanent position but in my experience it doesn't. I've seen many - not just me - but many of my colleagues have hit the dust. (Marie)

It is clear that the experience of income insecurity is central to the life course of casual academics, and that casual contracts produce insecurity as a key dimension of class subordination.

\section{Casual identity in the workplace}

Many interviewees stated that the primary reason the university had employed them was to save money on teaching. Many felt that they were simply the "cheaper option”. Asked why she thought the university employed casuals, Kate replies:

I assume it’s because it makes financial sense. Because if I was to sit down and look at the hours that I put into a course, to administer and teach and prepare to run these tutorials... I might be lucky to make $\$ 25$ an hour if I was to consider all the hours that I put in. (Kate)

The sense of alienation from the workplace is compounded by the lack of basic facilities, such as a space to store teaching materials. The symbolic importance of a place to put things, if not a place to sit, or a phone or computer to use, is greatly magnified. Scott conveys something of this 
in his comments:

I share a room with I don't know how many other people... you don't necessarily have a desk... I don’t have a dedicated phone number; I don’t have a dedicated computer... I’ve (at least) got my little cupboard, that's my office. (Scott)

Anna had her own solution to the absence of facilities - by adopting a marginal identity she could dismiss any illusions she may have:

I put myself into a carton and I thought ... that's quite good because it accentuates the temporary nature of this employment and it makes me not have any illusions that I'm anything except a very temporary employee. (Anna)

Molly speaks about the need to be self-sufficient:

It's pretty much do it yourself ... You learn to be completely independent and I think you find you're using a lot of your own resources at home, your computer at home, your printer at home, email, all that sort of stuff. (Molly)

In the process, casuals are physically isolated from the university community: the only contact is with subject coordinators who are their nominal workplace supervisors, and then only in a very limited sense. They are also isolated in terms of the intellectual community. Lola sees this as an important issue, not only in terms of her personal desire to be acknowledged, but also for the education of the students: 
Casuals have a lot to offer in terms of inputting about the way courses are run or issues of the process of teaching... they're used to the structure of the course, they understand the educational principles. There's a real kind of exclusion from that, which is a pity. (Lola)

Many casuals, like Lola, have been working in the same institution for a number of years, with entire degree programs reliant on them. These long-term casuals argue they are entitled to be employed on a continuing basis:

People, particularly like me obviously, who’ve worked here for a long time and who've demonstrated that they are committed to the place, they understand the place and they work well with the staff here, I'd like to see their jobs being converted into permanent part time jobs. (Alice)

For Damien the principle is simple: 'if you are an on-going employee you should not be employed casually'.

Over time, institutional marginality can feel like a personal insult. Several felt that they were putting a lot of work into an unresponsive system that took them for granted, and where they had no voice in the decision-making process. Juliet talks of the sense of disrespect: 'I just feel like we're a bit disposable to them...'

Positive stories hinged mainly on direct relationships with course supervisors and other colleagues. Access to facilities often relied on "chance” or "being around for a 
long enough time”. The sense of exclusion reflects the invisibility of casual work. Casuals are dispensable:

You're in and out of the place for a couple of days a week and if you can't do your job then someone else just does it. (laughs). If you leave the place, it’s not like it matters. (James)

The two-tier structure may be reinforced by students, who "sometimes perceive that the casuals are sort of on their side while the permanents are... they're the administration kind of” (Kaz). Crystal says "there’s a little bit of a class system” between permanent staff, who "have a say in and know the background [as] to why decisions are made”, and casuals. Barry is more adamant:

You're most definitely a second class citizen ... there is most definitely a hierarchy and some people, as in any environment, their position in that hierarchy is extremely important to them and they enforce it.

Fred puts it simply, saying he is “really aware” of his "pleb status'. The resulting sense of vulnerability can silence critical voices. Anna notes a common assumption:

Any casual lecturer is always conscious of the fact that you don't want to perhaps draw attention to yourself too much in case you're perceived as a nuisance or somebody who's requiring too much attention and so forth. 
Casuals are invisible in the academy, and are absent from the intellectual project of the university: contractual status translates directly into the experience of face-to-face subordination, and exclusion from decision-making.

\section{Conclusions}

Australia's higher education sector offers a strategic perspective on the causes and effects of casualisation, and how to address it. This research highlights the experience of academics in 'permanent casual' employment, a situation faced by an increasing proportion of the workforce, in Australia and elsewhere. The paradox of casual permanency stems from the increasing practice, under neo-liberal flexibilisation, of meeting continuing needs with non-continuing staff. Research into casual employment should, we argue, be focused on this anomaly, which is in danger of becoming the norm.

Our findings centre on the experience of class subordination by teaching casuals. First, we find that for casuals the issue of quality of education is subsumed into the question of payment-time for 'ancillary activities'. Quality is directly related, in the reported experience of casual staff, to their rate of self-exploitation. Second, we find that the life-course of the casual academic, in terms of their professional and intellectual trajectory and indeed in terms of personal development, is directly constrained by their casual status. Third, we find that casual staff are socially and intellectually alienated from the labour process: systemic exclusion, consequent upon contractual status, ostracises and subordinates casuals in the working environment. 
The reported expression of casual life in the flexible university parallels the wider process of neoliberalism. Neoliberal flexibilisation drives down the unit cost of labour (Harvey 2007) - and this is clearly evidenced in the case discussed here. But, the way it does this is by out-sourcing responsibilities and risks, thereby hollowing-out and casualising the workplace (Jessop 2002; Vosko 2006). Its impact is thus more than material. As reported here, university casualisation directly relates to issues of quality, security and collegiality. Casualisation individualises responsibility for quality and casuals self-exploit out of a sense of personal and professional obligation to students. Lacking income security, casual teachers become a highly responsive and manipulable pool of labour, bent to the will of the contract. Without access to the decision-making structures that define their work, casual teachers are not able to challenge collegial exclusion.

Importantly for any resulting conflicts, the key architects and beneficiaries of casualisation are absent from the point of (intellectual) production, in terms of academic teaching. The university displaces the structural class antagonism between senior management and casual staff into the face-to-face exclusion and subordination of casual staff by their continuing supervisors. Continuing academic staff do not materially exploit casual labour, but do preside over the systemic suppression of casual voices from the process of educational development. As reflected in our interviews, continuing staff are often conscious of this and make efforts to counteract its effects by seeking to informally include casuals in the intellectual community of the university. These efforts, and their significance for individual casuals, only serve to demonstrate the ingrained structural divide. 
As in other fields, neoliberal flexibilisation is ultimately self-destructive. In the higher education system there are at least three elements to this. The first relates to educational quality. Taylorism in the university factory, through casual teaching contracts that spell-out duties down to the last minute of waged labour, clearly has an effect on teaching quality. Faculties have created a gulf between casualised delivery and the pedagogical development of academic programs; universities now actively exclude students and teachers from the intellectual community, and from the production of knowledge. As noted earlier, the 2008 Bradley Review floated the proposition that the limit on casualisation, in terms of quality, had already been reached. Whether that warning bell was heard is a moot point, as casualisation is projected to grow.

The second limit is in the reproduction of labour power. As continuing staff from the Australian baby-boom generation retire en masse, and as higher education embarks on another phase of expansion driven by a new federal government, serious labour shortages are predicted (DEEWR 2008b, 5-7). For fifteen years universities have competed to reduce labour costs through casualisation, and have degraded the entrylevel labour market. Those who could leave the casual labour pool have already done so. Fewer suitably qualified staff are available, even for continuing positions when they are available. Unless the concerns of casuals, such as those outlined here, are addressed, the required intellectual capacity will not be available for Australian higher education, creating a 'looming shortage of academics' (Bradley et al 2008, p. xvi).

The third limit is mobilisation. In principle, the casuals themselves, working with continuing staff, have the capacity to force the issue. This casual 'periphery' of the 
academic labour market now performs almost half of all teaching activities in universities, and as such should move to the centre of union organising strategies. Clearly there are challenges here, in terms of disconnection from the workplace, but staff remain aggregated at particular campuses and as such can be mobilised. Many of the concerns expressed by casuals in this study, from teaching quality, to life course and decision-making, are potentially central to such any such mobilisation. A key overarching issue is the capacity to position casualisation as a threat to the academy as a whole, and specifically to continuing staff (Brown, Goodman and Yasukawa 2006, 2008).

Clearly universities could reintegrate academic teaching into the academy, and core teaching could be decasualised. But universities will not do this by choice. A 'perfect storm' may be approaching, with a crisis in quality, the implosion of academic labour supply, and a new academic militancy centred on reintegrating casuals. Perhaps only then may we see a reversal of the trends charted here.

\section{References}

Abbas A and McLean M (2001) Becoming Sociologists: professional identity for part-time teachers of university sociology, British Journal of Sociology of Education, 22(3): 339-352.

Australian Bureau of Statistics (2008) Social Trends, Cat. No. 4102.0, Canberra: ABS.

Australian Council of Trade Unions (2003a) Future of work: casual and insecure forms of work, Background Paper, Melbourne: ACTU.

Australian Council of Trade Unions (2003b) The future of work: trends and challenges in Australian workplaces, Melbourne: ACTU.

Australian Learning and Teaching Council (2008) The RED Report: Recognition, Enhancement, Development, The contribution of sessional teachers to higher 
education, Sydney: ALTC.

Australian Vice-Chancellors Committee (2003) Casual staff by function, Canberra: AVCC.

Australian Vice Chancellor's Committee (2004) “Laying the Foundations: the AVCC submission to the Review of the Indexation of University Funding”, http://www.avcc.edu.au/content.asp?page=/publications/policy/submissions/ind ex.htm, accessed 25 June, 2006.

Australian Vice Chancellor’s Committee (AVCC) (2005a) “Key Statistics - Students” http://www.avcc.edu.au/content.asp?page=/publications/stats/students.htm, accessed 25 June, 2006.

Australian Vice Chancellor’s Committee (AVCC) (2005b) “University Funding and Expenditure”

http://www.avcc.edu.au/content.asp?page=/publications/stats/fexp.htm, accessed 25 June, 2006.

Australian Vice-Chancellors Committee (2008) Student to teacher ratio: 1990-2006, Canberra: AVCC.

Berry J (2005) Reclaiming the Ivory Tower. New York: Monthly Review Press.

Bradley D, Noonan P, Nugent H and Scales B (2008) Review of Australian Higher Education: Final Report, Canberra: DEEWR.

Brown T, Goodman J and Yasukawa K (2006) Getting the Best of You for Nothing: casual voices in the Australian academy, National Tertiary Education Union: Melbourne.

Brown T, Goodman J and Yasukawa K (2008) Casualisation of Academic Work: Industrial Justice and Quality Education, Dialogue: Journal of the Academ y of the Social Sciences in Australia, 27(1): 17-29.

Bryson C (2004) What about the workers? The expansion of higher education and the transformation of academic work, Industrial Relations Journal, 35(1): 38-57.

Buchanan J (2004) Paradoxes of significance: Australian casualisation and labour productivity, paper prepared for ACTU, RMIT and The Age Conference 'Work Interrupted: casual and insecure employment in Australia', Hotel Sofitel, Melbourne, 2 August.

Campbell I (2004) Casual work and casualisation: how does Australia compare? paper prepared for ACTU, RMIT and The Age Conference 'Work Interrupted: 
casual and insecure employment in Australia’, Hotel Sofitel, Melbourne, 2 August.

Callinicos A (2006) Universities in a Neoliberal World. London: Bookmarks.

Cotterill P, Jackson S and Letherby G (2007) Challenges and negotiations for women in Higher Education. Amsterdam: Springer.

Department Education, Employment and Workplace Relations (2007) Selected Higher Education Statistics: Staff 2007, Canberra: DEEWR.

Department Education, Employment and Workplace Relations (2008) Students 2007 (full year): selected higher education statistics Summary Tables, Canberra: DEEWR.

Department Education, Employment and Workplace Relations (2008b) Review of Australian Higher Education: Discussion Paper, Canberra: DEEWR.

Gould E (2003) The university in a corporate culture. New Haven: Yale University Press:

Harvey D (2007) A brief history of neoliberalism, Oxford; Oxford University Press, Hayes D and Wynyard R (2002) The McDonaldisation of Higher Education. London: Routledge.

Husbands C and Davies A (2000) The teaching roles, institutional locations, and terms and conditions of part-time teachers in UK Higher Education, Journal of Further and Higher Education, 24(3): 337-362.

Jessop B (2002) The future of the capitalist state, Wiley-Blackwell, New Jersey. Junor A (2004) Casual university work: choice, risk, inequity and the case for regulation, The Economic and Labour Relations Review, 14(2): 276-304.

Kimber M (2003) The Tenured 'Core' and the Tenuous 'Periphery': the casualisation of academic work in Australian universities, Journal of Higher Education Policy and Management, 25(1): 41-50.

Marginson S. and Considine M. (2000) The enterprise university: power, governance and reinvention in Australia, New York: Cambridge University Press.

National Tertiary Education Union (2004) Membership Report: Employment status as a percentage of the total workforce/ NTEU membership, NTEU National Council Papers, Melbourne: NTEU.

Nelson C and Watt S (2004) Office hours: activism and change in the academy. London: Routledge. 
NSW Industrial Relations Commission (2006) Secure Employment Test Case (No 2), [2006] NSWIRComm 78, NSW Industrial Relations Commission, Sydney.

Percy A and Beaumont R (2008) The casualisation of teaching and the subject at risk, Studies in Continuing Education, 30(2): 145-157 July.

Pocock B, Prosser R and Bridge K (2004) 'Only a casual...' How casual work affects employees, households and communities in Australia, Labor Studies, Adelaide: University of Adelaide.

Probert B (2005) 'I just couldn’t fit in’: Gender and unequal outcomes in academic careers, Gender, Work and Organisation, 12(1): 50-72.

Productivity Commission (2006) The role of non-traditional work in the Australian labour market, Canberra: Productivity Commission, AGPS, May.

Ritzer G (1998) The McDonaldization thesis: explorations and extensions. New York: Sage.

Tuchman G (2009) Wannabe U: Inside the Corporate University. Chicago: University of Chicago Press.

Vosko L (2006) Precarious employment: understanding labour market insecurity in Canada. Montreal: McGill-Queens University Press.

Watson I, Buchanan J, Campbell I and Briggs C (2003) Fragmented Futures: New challenges in working life. Sydney: Federation Press.

Wooden M (1999) 'Job Insecurity and Instability: Getting the Facts Straight', Business Council of Australia Papers, 1(1): 14-18. 